\title{
Strategies for Managing Plastic Waste from Construction and Manufacturing Projects
}

\author{
Eng. Dickson Kwesiga \\ Manager Administration-Estates, Uganda Communications Commission, dkwesiga@gmail.com
}

\begin{abstract}
Plastics are inexpensive, lightweight and durable materials, which can readily be moulded into a variety of products that find use in a wide range of applications. Consequently, the production of plastics has increased markedly over the last 60 years. However, current levels of their usage and disposal generate several environmental problems. Plastics consume approximately $8 \%$ of world oil production: $4 \%$ as raw material for plastics and $3 \%$ to $4 \%$ as energy for manufacture. A major portion of plastic produced each year is used to make disposable items of packaging or other short-lived products that are discarded within a year of manufacture. These observations indicate that our current use of plastics is not sustainable. In addition, because of the durability of the polymers involved, substantial quantities of discarded end-of-life plastics are accumulating as debris in landfills and in natural habitats worldwide.
\end{abstract}

The manufacturing industry has developed considerably and so has the use of plastics. The growth has come with the challenge of plastic waste disposal which causes pollution. Plastic pollution involves the accumulation of plastic waste products in the environment that adversely affects wildlife, wildlife habitat or humans. Plastic pollution can unfavourably affect lands, waterways and oceans. This is not only evident in the marketplace; it is also evident at the conclusion of most manufacturing projects where the plastic is widely used for packaging and other short-lived products that must be discarded within a year of manufacture. Although efforts have been made to effectively handle the challenge there is still need to improve on the percentage of plastic waste from engineering projects that is recycled. According to Rugwiza (2012), only $1 \%$ of manufactures in Kampala have plastic recycling facilities.

The paper seeks to present the strategies under consideration in dealing with the problem. Reuse, recycling and reduce of the waste materials has been encouraged for many years; however, it is still not used for many construction site activities. Recycling is one of the most important actions currently available to reduce these impacts and represents one of the most dynamic areas in the plastics industry today. Recycling provides opportunities to reduce oil usage, carbon dioxide emissions and the quantities of waste requiring disposal. Plastic reduction efforts have occurred in some areas in attempts to reduce plastic consumption and pollution and promote plastics recycling. There has been remarkable growth in recycling of plastic materials in the last decade in Uganda. This has been helped by advances in technologies and systems for the collection, sorting and reprocessing of recyclable plastics. This has created opportunities and benefits for the environment as well as the economy.

With the combined effort of the manufacturing industry, the public and government, it may be possible to avert the dangers related to plastic waste and divert majority of the plastic waste from landfills to recycling. This will go a long way in ensuring green manufacturing projects with minimal effect to the environment.

Key Words: Plastic Waste, Construction, Manufacturing, Sustainability, 


\section{INTRODUCTION}

Solid waste management is one of the major environmental problems facing city municipalities today. In Kampala City, like other urban centres in Uganda, and in most other developing countries, this important service is based on the local government's centralized collection, transportation and disposal strategy (Nyakaana, 1997). Waste is defined as any material by-product of human and industrial activity that has no residual value (Serpell, \& Alarcon, 1998). Waste is created by the different activities that we get involved in. Plastic waste raises a huge challenge both locally and internationally.

Current data estimate that plastics represent $4 \%$ to $12 \%$ by volume of the solid waste stream. Precisely because of their large visibility, plastic wastes (and particularly non-durable plastic products) have been viewed as a serious solid waste problem. Waste generation in Uganda is between 1.2 and $3.8 \mathrm{~kg} / \mathrm{capita} / \mathrm{day}$ (low income $0.3 \mathrm{~kg} / \mathrm{capita} /$ day and high income $0.66 \mathrm{~kg} / \mathrm{capita} /$ day) (Okot-Okum, \&Nyenje, 2011). The average waste generation rate of $0.55 \mathrm{~kg} / \mathrm{cap} /$ day is comparable to NEMA (2007) results and also to other developing countries like Cameroon (Achankeng, 2003), Tanzania (Kaseva \& Mbuligwe, 2005) and Sri Lanka (Vidanaarachchi, Yuen, \& Pilapitiya, 2006).

Construction project contributed environmental pollution has been worsening along with the fast urban development since early 1980s (Zhang, Shen, Love, \& Treloar, 2000). Waste generated from building and demolition of construction projects assumes a large proportion of environmental waste (Poon, 1997). The major environmental impacts from construction activities are typically classified as air pollution, water pollution, waste pollution and noise pollution (EPD, 1999).

For decades, landfills had provided a convenient and cost-effective solution to solid waste management (Mills, Showalter, \& Jarman, 1999). However, the situation is changing. Wong and Tanner (1997) pointed out that the landfills, originally expected to last 40 to 50 years, would be filled faster, even if there were adequate outlets for construction and demolition (C\&D) materials. The major difficulty of the construction organizations to improve the environmental performance is an understanding of the current method on waste management and problems of the current methods.

Management of plastic waste is of key importance in construction and manufacturing projects because the way that the waste is handled, stored, collected and disposed of can pose a risk to the environment and public health. The practice of minimizing and diverting construction waste, demolition debris, and land-clearing debris from disposal and redirecting recyclable resources back into the construction process is commonly referred to as construction waste management (CWM). Construction is an example of a potentially very promising market for recycled plastic products. It is one of the largest industry in the country, thus providing a huge potential for waste plastic generation as well as potential market for recycled plastic products, especially at a time when the infrastructure is in urgent need for repair (Rebeiz, \& Craft, 1995).

\section{TYPES OF WASTE GENERATED}

The classification of urban waste generated in Uganda has been established during a composting project (NEMA, 2007) that indicated a composition of Biodegradable (76\%), Plastics (4\%), Metal (3\%), Polythene $(8 \%)$ and others $(9 \%)$. The average per capita solid waste generation rate is $1.284 \mathrm{~kg} / \mathrm{per}$ person/per day with a high organic content and bulky density. A study (NEMA, 2007) done in Uganda indicated methane emission potential from such urban wastes to vary between 0.9 and $4.12 \mathrm{Gg} / \mathrm{yr}$. Composting is being practiced in more than 11 urban councils of Uganda under the Clean Development Mechanism (CDM) pilot project promoted by the World Bank (NEMA 2007; Kumar 2006). 


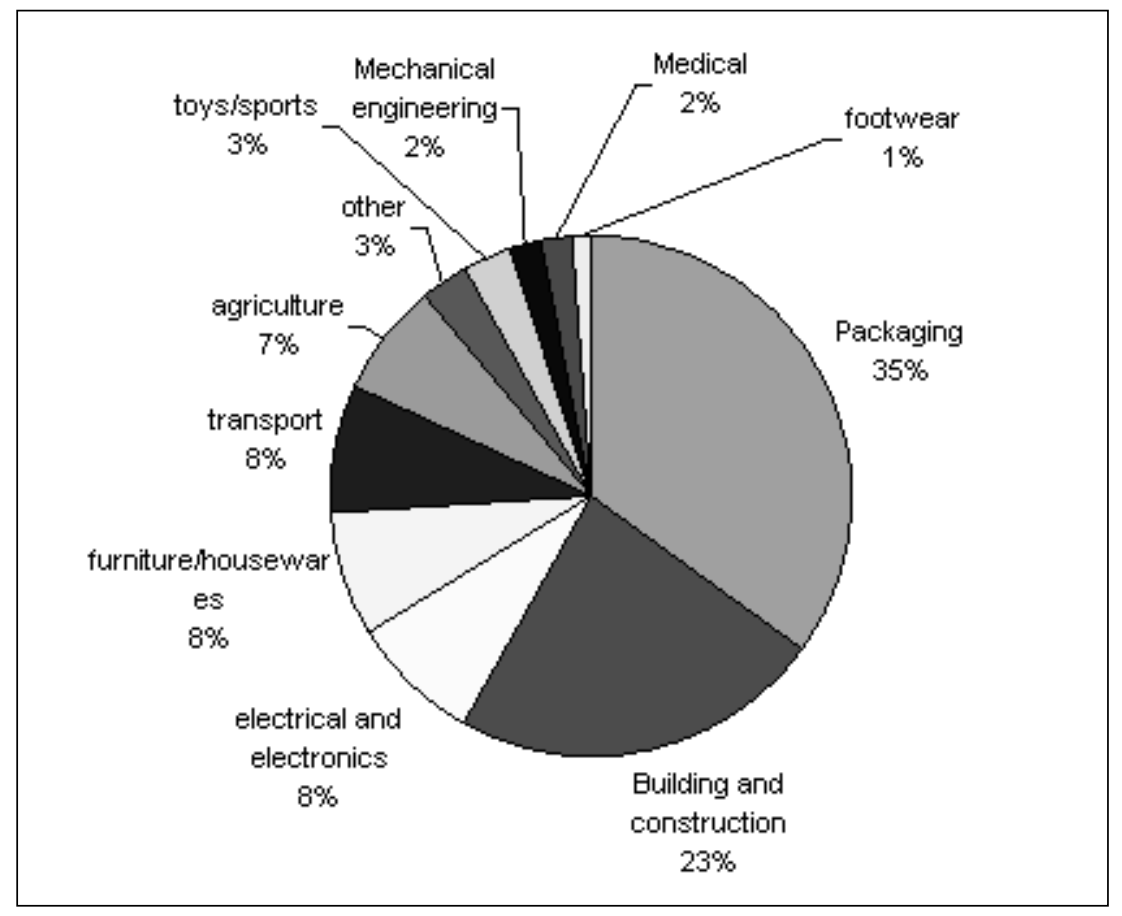

Figure 1: Utilization of plastic in various fields (Nkwachukwu et al., 2013)

\section{The Construction Waste Component}

The building and construction industry uses up to $23 \%$ of plastic manufactured (Figure 1). About 5.5 percent of the solid waste in landfills is waste from construction projects. However, these percentage varies greatly from urban to rural areas. The percentage of each construction waste material (wood, drywall, etc.) within each of the population groups is very similar but the amount of construction waste in large metropolitan areas is much higher than the rural areas (Table 1).

Table 1: Categorization of Solid Waste stream from Construction Projects (Napier, 2012)

\begin{tabular}{|l|l|}
\hline Material & \%age Weight \\
\hline Wood & 45 \\
\hline Drywall & 21 \\
\hline Masonry & 15 \\
\hline Metal & 1 \\
\hline Plastic & 4 \\
\hline Cardboard & 8 \\
\hline Other & 6 \\
\hline
\end{tabular}

In the construction industry, plastic is mainly used in: pipework, insulation, wall coverings and flooring, interior fittings, window frames, scaffolding boards and kerbstones. The common sources of plastic waste include: packaging (around 25 per cent of construction packaging waste), over ordering and disposal of offcuts and unused materials, over-specified project design, poor storage and handling and site workers' food packaging.

\section{Industrial Waste}


Industrial waste is difficult to define. In the broadest sense all waste from commercial operations could fall into the industrial category. It could include: Waste from an industrial, manufacturing, or commercial operation, Waste that was visibly homogeneous (all the same type of material) and Waste from a single waste generator and not combined with other generators.

However, it is difficult to separate some of this waste from the normal municipal solid waste. In many cases, the waste from small manufacturing, commercial, and institutional generators is collected in refuse trucks. These refuse trucks make hundreds of stops each day and combine the waste from each stop. In many cases the same truck that picks up residential waste will also pick up commercial and institutional waste.

\section{CURRENT STATUS OF MANAGING CONSTRUCTION \& MANUFACTURING WASTE}

Solid waste management in the urban areas of the country has been centralized. Refuse trucks are used to collect waste from the different sources and delivered to dumping areas (Rotich et al., 2006; Okot-Okumu \& Nyenje 2011).

The storage, collection, transportation and final treatment/disposal of wastes are reported to have become a major problem in urban centres (ADB 2002; Kaseva \& Mbuligwe 2005; Okot-Okumu \& Nyenje 2011; Rotich et al., 2006). The composition of wastes generated by the East African urban centres is mainly decomposable organic materials based on the urban community consumption that generates much kitchen wastes, compound wastes and floor sweepings (Oberlin, 2011; Okot-Okumu \& Nyenje 2011; Scheinberg, 2011; Simon, 2008; Rotich et al., 2006).

\section{Collection}

Collection of solid waste in the country has mainly been through the use of private contracted waste collectors who are contracted by the different sources for a fee. These move from door to door and have direct relationships with the individual clients.

Section IV (2) of the Kampala City Council (Solid Waste Management) Ordinance 2000 places the responsibility of collection of solid waste in the hands of Council in this case the KCCA and municipalities, either by its agents, servants or licensed collectors.

Section IV (7) of the KSWMO (2000) stipulates that the frequency of collection of solid waste shall be in accordance with the regulations of the collection agency but shall be regular enough (at least once a week) not to cause a public health nuisance.

Percent of waste collected in Kampala varies between 35\% and 68\% (Okot-okumu 2012). The introduction of private operators has increased solid waste collection levels compared when it was dependent on the urban councils (Kaseva \& Mbuligwe 2005; Okot-Okumu \& Nyenje 2011).

\section{BEST PRACTICES OF PLASTIC WASTE MANAGEMENT}

Several issues contribute to an overall waste diversion strategy. Effective management of construction project waste requires coordinated action of governmental, business, and professional bodies and their activities. Several non-governmental organizations and societies in Uganda promote coordinated action, and have identified best management practices in the interest of public health and welfare. 
Terminology for plastics recycling is complex and sometimes confusing because of the wide range of recycling and recovery activities. These include four categories: primary (mechanical reprocessing into a product with equivalent properties), secondary (mechanical reprocessing into products requiring lower properties), tertiary (recovery of chemical constituents) and quaternary (recovery of energy).

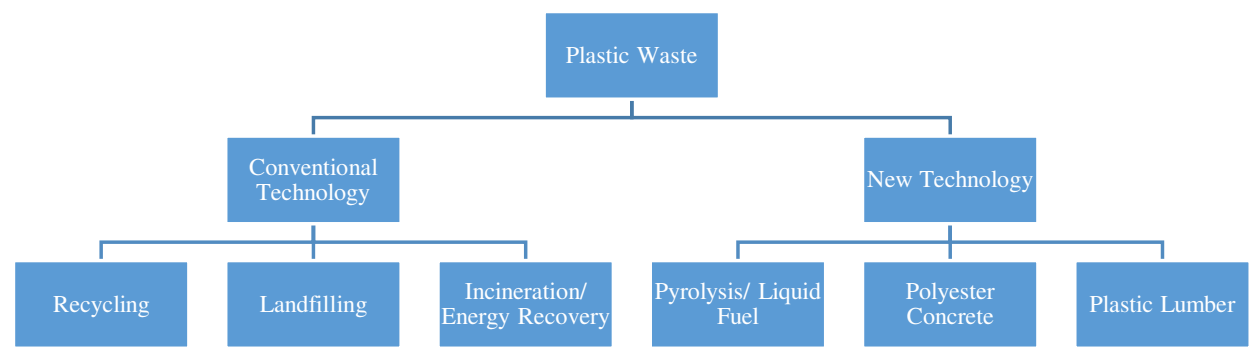

Figure 2: Plastic Waste Management

\section{PLASTICS RECYCLING}

Recycling is clearly a waste-management strategy, but it can also be seen as one current example of implementing the concept of industrial ecology, whereas in a natural ecosystem there are no wastes but only products (Frosch, \& Gallopoulos, 1989; McDonough, \& Braungart, 2002). Recycling of plastics is one method for reducing environmental impact and resource depletion. Fundamentally, high levels of recycling, as with reduction in use, reuse and repair or re-manufacturing can allow for a given level of product service with lower material inputs than would otherwise be required. A range of plastics can be recycled including: polyethylene terephthalate (PET), high density polyethylene (HDPE), low density polyethylene (LDPE), polypropylene (PP), polyvinyl chloride (PVC), polystyrene (PS), and ABS (a copolymer of acrylonitrile, butadiene and styrene) polymers.

However, there are some barriers to recycling plastic, particularly the related financial costs. For example: transportation costs - plastics are bulky and expensive to transport and store, separation costs - different varieties of plastic and mixed plastics contain different dyes and additives which produce poor quality recyclate unless separated, it can be cheaper and easier to use new plastic rather than recycled plastic and plastic can only be recycled once.

\section{Making changes to your site operations}

You can make simple yet effective changes to your site's operations to reduce plastic waste and allow more to be recycled by:

- separating plastic waste made of different polymers to reduce contamination

- providing staff with training in handling

- recovering materials and not sending to landfill

- improving transport procedures

- improving design - e.g. plastic pipe networks can be designed to use as few fittings as possible 


\section{Potential end uses for recovered plastic}

A large percentage of recycled plastics is made into extended-lifetime construction products, WRAP (2006), Young (2009), Eneh (2015), such as channels, insulation, fascias, damp proof membranes, water drainage, pipes and ducting, building blocks, roof tiles, decking, fencing and outdoor furniture. It can also be used in many other applications including: as a filler (thermoset plastics), packaging, landscaping - e.g. walkways, jetties, pontoons, bridges, fences and signs, textile fibre and clothing - polyester fleece clothing and polyester filling for duvets and coats is frequently made from recycled bottles, street furniture - e.g. seating, bins, street signs and planters, bin liners and refuse sacks, and traffic management products and industrial strapping.

Analysing parameters as a function of the specific building site will make it possible to implement a realistic sorting scenario.

1. Waste Management Planning: Waste management should be an integral part of a project's development.

2. Facility Design: The Contractor is responsible for the means, methods, techniques, sequences, and procedures of construction which include waste disposal methods.

3. Construction Contract Requirements: The Owner and their consultant must determine how their waste management requirements will be represented in the contract documents and incorporated into the project.

4. Jobsite Waste Reduction: There are a variety of ways a Contractor can divert construction waste or demolition debris at the jobsite. The following general practices are common.

If none of the alternative salvage, reuse, or recycling options are possible, mixed demolition debris can be hauled to a debris recycling facility.

\section{EMERGING ISSUES}

\section{Synthetic Lightweight Aggregate technology (SLA) (Kashi, 2001)}

SLA are manufactured from two materials, waste plastics, and fly ash, through disposal facilities. SLA are produced by melt compounding high concentrations of fly ash from coal with various thermoplastics. The compounding equipment used in this step, is a 30-mm inter-meshing; counter rotating twin-screw extruder with a medium/high shear profile screw configuration. The Thermoplastic binder material is starve-fed into the feed section of the twin screw using a single screw auger feeder. The technology is being considered in Taiwan (Tang, 2013), in Kuwait (KISR, 2016) and the United States of America (Mallick, Hooper, O’Brien, \& Kashi, 2004).

\section{Polymer Concrete}

Polymer concretes are a type of concrete that use polymers to replace lime-type cements as a binder. In some cases the polymer is used in addition to Portland cement to form Polymer Cement Concrete (PCC) or Polymer Modified Concrete (PMC) (Kim, 1994) Polymers in concrete have been overseen by Committee 548 of the American Concrete Institute since 1971. In polymer concrete, thermoplastic polymers may be used, (Figovsky, \& Beilin, 2013) but more typically thermosetting resins are used as the principal polymer component due to their high thermal stability and resistance to a wide variety of chemicals. 


\section{Pyrolysis of Waste Plastics into Fuels}

Pyrolysis is the chemical decomposition of condensed organic substances by heating. The word is coined from the Greek-derived elements pyro "fire" and lysys "decomposition". Pyrolysis is usually the first chemical reaction that occurs in the burning of many solid organic fuels, like wood, cloth, and paper, and also of some kinds of plastic. Anhydrous pyrolysis can also be used to produce liquid fuel similar to diesel from plastic waste, with a higher cetane value and lower sulphur content than traditional diesel. Using pyrolysis to extract fuel from end-of-life plastic is a second-best option after recycling, is environmentally preferable to landfill, and can help reduce dependency on foreign fossil fuels and geo-extraction (Themelis, Castaldi, Bhatti, and Arsova, 2011). The technology is being applied in India (Ali, 2013).

\section{CONCLUSIONS AND RECOMMENDATIONS}

With the combined effort of the manufacturing industry, the public and government, it may be possible to avert the dangers related to plastic waste and divert majority of the plastic waste from landfills to beneficial use. This will go a long way in ensuring green manufacturing projects with minimal effect to the environment. This is useful to human existence, serving to maintain life and supporting the depleting ozone layer; the subject-matter of climate change and its adverse consequences currently being experienced in many parts of the world.

\section{Recommendation}

Emerging trends in waste plastic management should be considered and researched to widen the range of recycling options. This will improve the economic benefits of recycling as well as the viability and sustainability of plastic waste management especially in the construction and manufacturing industries.

It is possible to replicate all the technologies involved in the processes of plastic waste-recycling, especially in the East African region by encouraging Research in Recycling. Universities should encourage research in plastic waste recycling, establish workshops and materials-testing laboratories. Inter university exchanges, especially with advanced and recognized universities should be encouraged. The large volume of materials required for construction offers a potentially major area and attraction for reuse in other sectors outside construction.

\section{REFERENCES}

[1] ADB., (2002). Report Prepared for Sustainable Development and Poverty Reduction Unit: Solid Waste Management Options For Africa. Côte dÍvoire

[2] Achankeng, E. (2003). Globalization, urbanisation and municipal solid waste management in Africa. In Proceedings of African Studies Association of Australasia and the Pacific: African on a global stage.

[3] Ali, A. (2013). Polymer Concrete as Innovative Material for Development of Sustainable Architecture. $\quad$ Retrieved $\quad$ May 25, 2016, from https://www.researchgate.net/publication/269701774_Polymer_Concrete_as_Innovative_Mater ial_for_Development_of_Sustainable_Architecture

[4] Figovsky, O., \& Beilin, D. (2013). Advanced polymer Concretes and compounds. United States: CRC Press.

[5] EPD (Environmental Protection Department) (1999). Environment Hong Kong Annual Report 1999. Hong Kong Government, 8-15. 
[6] Andrady, A. L. (Ed.). (2003). Plastics and the environment. United States: Wiley-Interscience.

[7] Frosch, R. \& Gallopoulos, N. (1989). "Strategies for manufacturing." Sci. Am., Vol. 261, 144 152.

[8] Hopewell, J., Dvorak, R., \& Kosior, E. (2009). Plastics recycling: challenges and opportunities. Philosophical Transactions of the Royal Society B.

[9] Kaseva, M. E., \& Mbuligwe, S. E. (2005). Appraisal of solid waste collection following private sector involvement in Dar es Salaam. Habitat International, 29, 353-366.

[10] Kashi, M. (2001) "Synthetic Lightweight Aggregate for Highway Construction" The Recycled Material Resource Center. University of New Hampshire.

[11] Kim, D., (1994). Composite structures for civil and architectural engineering. United Kingdom: Taylor \& Francis.

[12] KISR. (2016). Kuwait institute for scientific research - projects. Retrieved May 25, 2016, from http://www.kisr.edu.kw/en/research/energy-and-building/projects

[13] Kumar, S.N. (2006). Report on Setting up compost Plants for Municipal Solid wastes in Uganda. EMCBP- II World Bank \& National Environment Management Authority, Kampala Uganda.

[14] Mallick, R., Hooper, F., O’Brien, S., \& Kashi, M. (2004). Evaluation of use of synthetic lightweight aggregate in hot-mix asphalt. Transportation Research Record: Journal of the Transportation Research Board, 1891, 1-7.

[15] McDonough, W. \& Braungart, M. (2002). "Cradle to cradle: remaking the way we make things New York." NY: North Point Press

[16] Mehta, P. K., Monteiro, P. J. M., Mehta, K. P., \& Monteiro, J. M. (2013). Concrete: Microstructure, properties, and materials (4th ed.). New York: McGraw-Hill Professional.

[17] Mills, T.M., Showalter, E. and Jarman, D. (1999) A cost-effective waste management plan. Cost Engineering, 41(3), 35-43.

[18] Napier, T. (2012), Construction Waste Management, U.S. Army Corps of Engineers, Engineer Research and Development Center / Construction Engineering Research Laboratory

[19] National Environment Management Authority (NEMA). (2007). Clean development mechanism (CDM) e Uganda solid waste composting project. Analysis report.

[20] Nyakaana, J. (1997) 'Solid Waste Management in Urban Centre', East African Geographical Review 19(1): 33-43.

[21] Oberlin, A.S., (2011). The Role of Households in Solid Waste Management in East Africa Capital Cities. PhD Thesis. Environmental Policy Series. Wageningen University. The Netherlands.

[22] Okot-Okumu, J., and R. Nyenje. (2011). "Municipal solid waste management under decentralisation in Uganda." Habitat International no. 35:6

[23] Poon, C.S. (1997) Management and Recycling of Demolition Waste in Hong Kong. Waste Management and Research Vol 15, 561-572.

[24] Rebeiz, K. S., Craft, A. P. (1995) "Plastics Waste Management in Construction: Technological and Institutional Issues", Resources, Conservation and Recycling, Vol.15, pp.245-257.

[25] Ricardo-AEA/R/ED58135. Case Study 3: Cynar Plastics to Diesel. Zero Waste South Australia 2013. 
[26] Rotich, H. K.; Yongsheng, Z; \& Jun, D. (2006). Municipal solid waste management challenges in developing countries: Kenyan case study. Waste Management 26 (1), 92-100

[27] Scheinberg, A., Spies, S., Simpson, M. H., \& Mol, A. P. J. (2011). Assessing urban recycling in low- and middle-income countries: Building on modernised mixtures. Habitat International, 35(2), 188-198.

[28] Serpell, A., \& Alarcón, L. F. (1998). Construction process improvement methodology for construction projects. International Journal of Project Management, 16(4), 215-221.

[29] Simon A.M., (2008). Analysis of Activities of Community Based Organizations Involved in Solid waste Management, Investigation Modernized Mixtures Approach. The Case of Kinondoni Municipality, Dar es Salaam. MSc Thesis. Wageningen University.

[30] Song, J. H., Murphy, R. J., Narayan, R., \& Davies, G. B. H. (2009). Biodegradable and compostable alternatives to conventional plastics. Philosophical Transactions of the Royal Society B: Biological Sciences, 364(1526), 2127-2139.

[31] State of Environment Report for Uganda 2006/7. NEMA, Kampala.357pp.

[32] Tam, V. W. (2014). Recovery of Construction and Demolition Wastes. Handbook of Recycling, 385-396.

[33] Themelis, N.J., Castaldi, M.J., Bhatti, J., and Arsova, L., (2011) Energy and Economic Value of Non-Recycled Plastics (NRP) and municipal solid wastes (MSW) that are currently landfilled in the fifty states. Earth Engineering Center, Columbia University, Genova, Italy

[34] Vidanaarachchi, C. K., Yuen, S. T. S., \& Pilapitiya, S. (2006). Municipal solid waste management in the southern province of Sri Lanka: Problems, issues and challenges. Waste Management, 26(8), 920-930.

[35] Water Aid, (2011) Solid Waste Management Arrangements and its Challenges in Kampala: A case Study of Bwaise II Parish, Kawempe Division, Kampala, Uganda

[36] Wong, A.Y.S. and Tanner, P.A. (1997) Monitoring environment pollution in Hong Kong: trends and prospects. Elsevier Science 16(4), 180-190

[37] Zhang, Z.H., Shen L.Y., Love, P. and Treloar, G. (2000) A framework for implementing ISO 14000 in construction. International Journal of Environmental Management and Health 11(2), $145-148$. 